\title{
DOMESTIC ACTIVITIES AND PM GENERATION: A CONTRIBUTION TO THE UNDERSTANDING OF INDOOR SOURCES OF AIR POLLUTION
}

\author{
M. SCHIAVON ${ }^{1,2}$, E.C. RADA ${ }^{2}$, M. RAGAZZI ${ }^{2}$, S. ANTOGNONI ${ }^{2}$ \& S. ZANONI ${ }^{2}$ \\ ${ }^{1}$ Fondazione Trentina per la Ricerca sui Tumori, c/o Department of Civil Environmental and \\ Mechanical Engineering, University of Trento, Italy. \\ ${ }^{2}$ Department of Civil, Environmental and Mechanical Engineering, University of Trento, Italy.
}

\section{ABSTRACT}

Few researches on domestic indoor air pollution have given quantitative information on the variation of the characteristics of the indoor source of particulate matter (PM). The purpose of this work was to investigate the emission characteristics of the common indoor particle sources.

More specifically, this paper is intended to contribute to the understanding of how normal domestic activities could affect the human health. The emission sources of PM studied in this work was cooking, vacuuming, ironing and the use of deodorant spray.Cooking activities were expected to be one of the major sources of indoor particles and the features of the cookers may affect the characteristics of emissions resulting from cooking. For this reason, the results of a previous study based on the variability of the power of the cooker were reported, to study the sustainability of natural gas from the point of view of the induced indoor human exposure to PM.

Measurements were performed by a GRIMM analyser, able to measure 16 granulometric classes from 0.3 to $20 \mu \mathrm{m}$. The study found that the activity of cooking and the use of deodorant spray are the sources that produce the higher indoor concentration levels compared with the other sources studied.

Keywords: cooking, indoor activity, indoor air, natural gas, particulate matter.

\section{INTRODUCTION}

Over the past three decades, the atmospheric particulate matter (PM) has been the subject of numerous studies and has shown growing interest by decision makers and public opinion referring to various sectors [1-8]. PM plays a vital role in climate change on a global scale, because it changes the properties on absorption and reflection of the atmospheric air, thus causing a greater overheating on the ground $[9,10]$. PM also has a strong impact on local scale with important implications for human health: epidemiological studies have highlighted the strong correlation between air pollution and pulmonary and cardiovascular diseases, respiratory irritation and disturbances of visual nature. Continued exposure (long-term) can also lead to the occurrence of cancer diseases $[11,12]$.

There is usually more information available on emission characteristics, such as emission factors or emission rates, of outdoor particle sources than of indoor sources [13-15]. However, quantification of emissions from indoor sources is very important for the assessment of the total human exposure to particles.

Monitoring activities were performed in all the continents as demonstrated by the scientific literature [16-21]. Sites in low-income [22], medium-income [23] and high-income [24] countries around the world were studied to generate data useful for the assessment of human exposure to PM. Even remote sites were investigated for a background comparison [25]. Some researches zoomed from regional monitoring [26] to urban areas [27]. Other researches focused on specific mobile sources $[6,7,28,29]$, on the finest fractions of PM [30], on the seasonal variability of the PM concentration values [10] and on the specific contribution of point sources [13].

The problem of air contamination in indoor environments has always been neglected and only recently, the international scientific community has begun to show interest in this issue, especially 
considered that, at the European level, the majority of the population spends up to $80 \%$ of their day in indoor environments [31]. Particular attention was made to indoor concentrations in workplaces [27]. Recent studies focused on specific indoor environments such as pizzerias [32], hospitals [33], schools [34] churches [35] and tunnels [36].

An important role in indoor air quality (IAQ) is played by the characteristics of the fuel burned for heating and energy purposes; major problems in terms of suspended particles are given by the low vapour pressure and high sulphur content, typical of kerosene, for instance, and of biomass of poor quality $[3,26,37]$.

The most significant indoor sources include tobacco smoking, cooking, kerosene heating and wood burning [38]. Other sources or human activities contributing to elevated levels of indoor particles include re-suspension of particles by people or pets, dusting and vacuuming, showering, operation of humidifiers or electric motors. Contributions from outside were also reported and estimated in 32-45\% for $\mathrm{PM}_{10}, 67-76 \%$ for $\mathrm{PM}_{2.5}$ and 79-83\% for $\mathrm{PM}_{1.0}$ in a recent study [39]. Outdoor contributions seem to be important also for polycyclic aromatic hydrocarbons (PAHs) and, especially for benzo(a)pyrene, which contributes to about 50\% of the cancer risk [40]. Another study highlighted the higher concentration of organic carbon (OC) and the lower concentration of elemental carbon (EC) in indoor environments with respect to the outdoor situation [41]. EC is mostly generated by road traffic; thus, the lower contribution of EC and the higher contribution of OC indoors suggest the dominant influence of other sources in closed environments. OC (especially non-combustion OC), in indoor environments, derives mostly from cooking activities [42].

The chemical composition of indoor PM is particularly influenced by the sources present in the indoor environment: PAHs were found to basically mirror the spectra of outdoor measurements in offices, whilst bisphenol A resulted higher indoors in one study [43], probably due to the electronic equipments in use. Bioparticles (e.g. polyols and sugars) are the dominant constituents of $\mathrm{PM}_{10}$ in indoor environments, followed by acids (palmitoleic and linoleic acids) whose generation is attributed to cooking activities [44]. On the other hand, outdoor air is characterized by a relatively higher contribution of other species (aliphatics, PAHs and $n$-alkanols). Unsaturated fatty acids and PAHs (including some carcinogens, such as benzo[a]pyrene) are products of the cooking of animal fat and meat [45].

Ultrafine particles (UFP) play an important role in indoor environments: indoor-generated PM is characterized by a unimodal size distribution whose maximum in terms of number of particles is located between 0.02 and $0.1 \mu \mathrm{m}$ (the Aitken mode) [46]. Although the outdoor PM presents a bimodal distribution (the nucleation mode), with a maximum at lower diameters (around $0.01 \mu \mathrm{m}$ ), the concentrations normally achieved through cooking and other indoor activities may be, on average, one order of magnitude higher than outdoors. If not generated in indoor environments, UFP can penetrate from outside and remain suspended in the air for long periods [47]. Condensation of particles and their conversion to particles of larger dimensions were also observed, in spite of the slowness of the process, which may last for some hours [48]. On a mass basis, the larger surface area of UFP seems to be responsible for inducing more inflammation than coarse particles [49]. In spite of the still scarce knowledge on the health effects of UFP, their passage into blood and their role in promoting the thrombosis process was demonstrated [49]. Oxidative DNA damage was also found to be correlated with cumulative exposure to UFP in healthy subjects, whilst an increase of the symptoms of asthma and a reduction in lung function were observed for asthmatic people [50]. In addition, an increased risk of developing bronchitis was associated with mass concentration of particles smaller than $1 \mu \mathrm{m}$ and number concentration of particles bigger than $0.5 \mu \mathrm{m}$ in children [51]. The health effects of UFP, however, depend also on the chemical composition of particles. Volatile organic compounds (VOCs), for instance, are mostly found in fine particles [52] and are composed 
also of carcinogenic pollutants, such as benzene and ethyl benzene. The same conclusions were drawn for PAHs, which tend to concentrate on particles of size lower than $0.7 \mu \mathrm{m}$ [53].

Given the dimensions of the problem, this paper is intended to contribute to the understanding of the role of indoor activities, referring to specific cooking procedures performed under different conditions and other activities that are normally carried out in houses, such as ironing, vacuuming or the use of deodorant spray.

Since $\mathrm{PM}_{10}$ is not adequate for a complete vision of the human exposure to particulate matter, the instrument chosen for the experimental activities was an analyser able to measure also lower granulometric classes. The detail on particles smaller than $0.3 \mu \mathrm{m}$ will not be available in this study, due to incapability of the instrument to detect particles whose diameter is lower than this size.

In the past, the United States was one of the first conutries establishing standards of air quality. Initially, attention was paid on the total suspended particulate [54] but soon a 3-year average of the annual mean concentrations for $\mathrm{PM}_{10}$ and $\mathrm{PM}_{2.5}$ was introduced, equal to 50 and $15 \mu \mathrm{g} \mathrm{m}^{-3}$, respectively [55]. Even the European Union in 1999 established ambient air quality limit values for $\mathrm{PM}_{10}$ in the European Directive 1999/30/EC: the annual mean concentration limit was set to $50 \mu^{-3} \mathrm{~m}^{-3}$ not to be exceeded more than 35 times per year and the daily mean concentration limit was set to $40 \mu \mathrm{g}$ $\mathrm{m}^{-3}$ [56]; for $\mathrm{PM}_{2.5}$, only the implementation of measures aimed at its reduction was planned, without providing a concentration limit of reference. In April 2008, the European Union adopted the Directive 2008/50/EC about outdoor air quality [57], which confirmed the limit values for $\mathrm{PM}_{10}$ and introduced the annual mean concentration limit for $\mathrm{PM}_{2.5}$, equal to $25 \mathrm{~g} \mathrm{~m}^{-3}$.

At European level, the guidelines born over the last 10 years in European countries (e.g. the Netherlands, Finland, Norway) and beyond (United States, Canada, Singapore) can be taken into account; such guidelines have the advantage of indicating precise values of concentration for PM to be used in indoor environments. The American Standard ASHRAE [58] gives a further contribution to the field. The limits for $\mathrm{PM}_{2.5}$ are $15 \mu \mathrm{g} \mathrm{m} \mathrm{m}^{3}$ (annual exposure) and $35 \mu \mathrm{g} \mathrm{m}{ }^{3}$ (daily exposure), while for $\mathrm{PM}_{10}$ are $50 \mu \mathrm{g} \mathrm{m}^{3}$ (annual exposure) and $150 \mu \mathrm{g} \mathrm{m}{ }^{3}$ (daily exposure).

\section{MATERIALS AND METHODS}

The main tool used for the measurements is the GRIMM analyser 1.108 [59]. This tool is similar to the one adopted in a recent research on indoor air pollution [60]. This instrumentation measures 16 granulometric classes from 0.3 to $20 \mu \mathrm{m}$. This tool allows assessing PM with different diameters. The values taken into account in this paper for the developed case study are $\mathrm{PM}_{10}, \mathrm{PM}_{2.5}$ and $\mathrm{PM}_{1.0}$.

The ambient air to be analysed is drawn into the unit via an internal volume-controlled pump at a rate of $1.2 \mathrm{~L} / \mathrm{min}$. The sample passes through the sample cell, through the laser diode detector and is collected onto a 47-mm filter. The entire sample can then be analysed gravimetrically for the verification of the reported aerosol mass. The pump also generates the necessary clean air, which is filtered and passes through the air regulator back into an optical chamber. This is to ensure that no dust contamination comes in contact with the laser-optic assembly. Data are also available via the built-in serial port. These data, available in intervals between 6 and $60 \mathrm{~s}$, can be transmitted to an external computer. The particle size analyser/dust monitor determines the dust concentration through the optical-light-scattering method directly. It must be pointed out that this method is generally not used as the official one: the Environmental Agencies typically adopt gravimetric methods according to the present regulations. If we consider the aim of the present research, the used tool is suitable in order to obtain significant scientific results about PM generation varying the characteristics of an indoor source. PM samplings were coupled with measurements of air temperature and relative humidity, performed by means of the digital thermo-hygrometer BAR 122 HGN (Oregon Scientific Ltd, Portland). 
For the development of the present research, the GRIMM instrument was placed in the centre of a selected kitchen, $2 \mathrm{~m}$ away from the stove location. This choice was made in order to simulate the exposure of people sitting at the table. The selected room is square-shaped, measuring $4.5 \mathrm{~m}$ on each side and with a 2.6-m height.

In a previous study [61] about cooking with different thermal powers, the research concerned the cooking of beef-steaks, each weighing about $200 \mathrm{~g}$. Neither oil nor dressing was used. All the steaks were well-done. Three natural gas cookers, with different thermal powers, $1.65,2.3$ and $3 \mathrm{~kW}$, were used.

In the present experiment, a series of tests were carried out in a kitchen to investigate two different types of cooking, an activity that is presumed to be one of the main indoor sources of particulate matter in a residential building. The kitchen adopted has a volume of $53 \mathrm{~m}^{3}$ and a horizontal surface of $25 \mathrm{~m}^{2}$. Two situations were analysed: cooking a pork chop on the cast iron plate and the preparation of polenta on the grill (Fig. 1).

The surface layer of the cast iron plate was sprinkled with a fine layer of extra virgin olive oil that has been heated before placing the steak (about $200 \mathrm{~g}$ ) on the natural gas. The cooking lasted about $20 \mathrm{~min}$. In the second part of the experiment, five slices of polenta with a thickness of $2 \mathrm{~cm}$ were cooked on a grill placed on the same cooker. The cooking phase lasted about twenty minutes, preceded by a pre-heating of the grill on fire. The room was not equipped with a fume hood. The windows were opened at the end of the test, approximately $1 \mathrm{~h}$ after the lighting of the fire and about $40 \mathrm{~min}$ after the extinguishing.

The purpose of an additional experiment was to monitor the levels of PM that can be achieved in a closed non-aerated room due to the use of a common deodorant spray for personal hygiene product. The room has a volume of $20 \mathrm{~m}^{3}$ and a surface of $7.5 \mathrm{~m}^{2}$. The test was preceded by a preliminary ventilation of the room, followed by a phase of calm with doors and windows closed, in which the instrument was switched on to get feedback on the background levels of PM in the room. Then, two squirts of the spray (for a total of $2 \mathrm{~s}$ in the first two tests and $1 \mathrm{~s}$ in the third) were released in front of a mirror up to a height of $1.70 \mathrm{~m}$. The instrument was placed in the centre of the room at a height of $1.60 \mathrm{~m}$.

The action of an iron in a closed and poorly ventilated room (volume of $44 \mathrm{~m}^{3}$ and horizontal surface of $17 \mathrm{~m}^{2}$ ) was expected to lead to an increase in PM concentrations. The iron used has an aluminium plate, a power of $1400 \mathrm{~W}$ and is equipped with an external tank with a capacity of
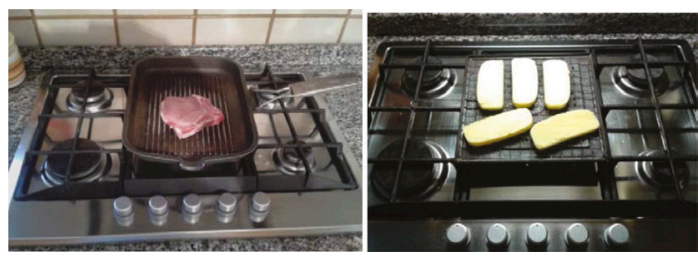

Figure 1: (a) Cast iron plate for the cooking of pork chops and (b) grill for the cooking of polenta.
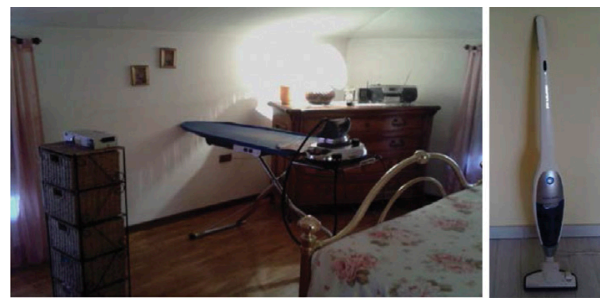

Figure 2: (a) Ironing board and (b) vacuum cleaner adopted for the experiments. 
$800 \mathrm{~mL}$ to produce steam. The instrument was placed in front of the ironing board at a distance of $1.80 \mathrm{~m}$ from the analyser (Fig. 2).

In a last experiment, the efficiency of the vacuum cleaner of the house and the changes in PM that occur during removal activities of the dust deposited on the floors were monitored. The vacuum cleaner used has a power of $1800 \mathrm{~W}$ (Fig. 2).

Some recent surveys indicated that vacuum cleaners with bag are not capable of retaining fine dust (with from $<2.5 \mu \mathrm{m}$ ) so that they can bypass filters and can be readmitted into the environment after passing through an unhealthy place as the domestic vacuum cleaner, where mites, insects, organic matter and decomposing substances can be found [62]. The instrument was placed in the centre of a room (volume of $65 \mathrm{~m}^{3}$ and horizontal surface of $25 \mathrm{~m}^{2}$ ) on a small ladder at a height of $0.90 \mathrm{~m}$.

\section{RESULTS AND DISCUSSION}

Three cooking tests were carried out on the pork chop placed on the cast iron plate; similarly, three cooking tests were performed on the preparation of polenta on the grill.

The cooking of a pork chop on the plate released a large amount of PM in the environment: a substantial fraction is represented by fine particles, the most dangerous to human health (Table 1). During the recording of the measurements, the air temperature in the room ranged from $26.4^{\circ} \mathrm{C}$ to $28.6^{\circ} \mathrm{C}$, whilst the relative humidity was between $37 \%$ and $44 \%$. In all the simulations, a sudden growth of the peak concentrations is visible, reached at the final stages of the cooking when a persistent smoke was released. For reasons of visibility, only the time-depending concentrations related to the cooking of the second chop (Chop 2) are reported (Fig. 3).

The tests showed that concentrations of $\mathrm{PM}_{2.5}$ and $\mathrm{PM}_{1.0}$, after reaching their maximum, decreased slightly over time, even after the conclusion of the cooking operations, with consequent repercussions

Table 1: PM measurement during the cooking of pork chops.

\begin{tabular}{lcccccc}
\hline & $\begin{array}{c}\text { Average } \\
\mathrm{PM}_{1.0}\end{array}$ & $\begin{array}{c}\text { Average } \\
\mathrm{PM}_{2.5}\end{array}$ & $\begin{array}{c}\text { Average } \\
\mathrm{PM}_{10}\end{array}$ & $\begin{array}{c}\text { Maximum } \\
\mathrm{PM}_{1.0}\end{array}$ & $\begin{array}{c}\text { Maximum } \\
\mathrm{PM}_{2.5}\end{array}$ & $\begin{array}{c}\text { Maximum } \\
\mathrm{PM}_{10}\end{array}$ \\
\hline Unit & $\mu \mathrm{g} \mathrm{m}^{3}$ & $\mu \mathrm{g} \mathrm{m}^{3}$ & $\mu \mathrm{g} \mathrm{m}^{3}$ & $\mu \mathrm{g} \mathrm{m}^{3}$ & $\mu \mathrm{g} \mathrm{m}^{3}$ & $\mu \mathrm{g} \mathrm{m}^{3}$ \\
Chop 1 & 184.1 & 340.5 & 803.5 & 303.4 & 532.5 & 1774.2 \\
Chop 2 & 195.9 & 415.5 & 962.9 & 343.4 & 714.2 & 2135.2 \\
Chop 3 & 670.7 & 862.2 & 1158.4 & 1049.2 & 1344.1 & 2039.5 \\
\hline
\end{tabular}

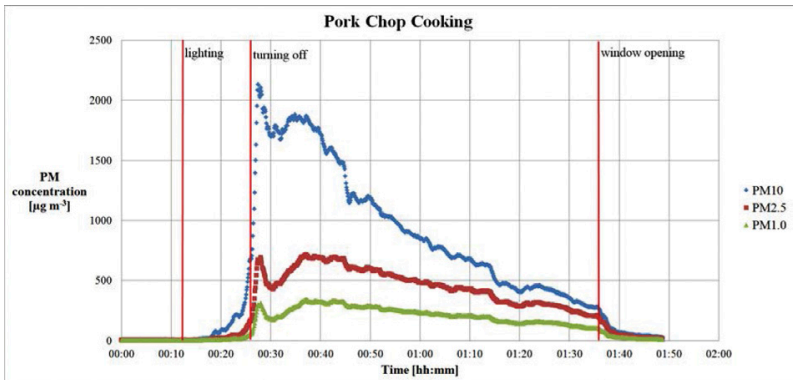

Figure 3: PM concentration during the cooking of Chop 2; the vertical red lines indicate the lighting, the turning off the cooker and the window opening. 
on the IAQ; on the other hand, particles with greater dimensions tend to deposit more rapidly. During test 3, the maximal values for $\mathrm{PM}_{2.5}$ and $\mathrm{PM}_{1.0}$ were, respectively, double and quadruple compared with the previous cases, due to the fact that the plate was not perfectly clean at the time of the trial, still presenting traces of oil. A lower average $\mathrm{PM}_{2.5}$ concentration $\left(130 \mu \mathrm{g} \mathrm{m}{ }^{3}\right)$ was measured in a kitchen of a dwelling in Singapore, characterized by very similar conditions in terms of ambient air temperature, relative humidity, fuel in use and absence of extraction system [63]. On the other hand, the concentrations here measured are similar to the ones observed in a survey on naturally ventilated houses in Mexico where cooking activities were carried out with natural gas, even though higher maximal concentrations were measured (8899; 7182 and $4822 \mu \mathrm{g} \mathrm{m}^{3}$ for $\mathrm{PM}_{10}, \mathrm{PM}_{2.5}$ and $\mathrm{PM}_{1.0}$, respectively) [64]. Lower peaks (less than 350 and $250 \mu \mathrm{g} \mathrm{m}{ }^{3}$ for $\mathrm{PM}_{10}$ and $\mathrm{PM}_{1.0}$, respectively) with respect to the present study were measured in a kitchen while the windows were open [21].

Even in the case of cooking polenta, a sudden increase in PM concentration was detected (Table 2), followed by a slow decline that begins after stopping the action of cooking on the stove and that lasts for a long time (Fig. 4). In this test, $\mathrm{PM}_{2.5}$ and $\mathrm{PM}_{1.0}$ maximal concentrations are similar to the ones reached in the previous case, whilst $\mathrm{PM}_{10}$ concentrations are lower and comparable with $\mathrm{PM}_{2.5}$ and $\mathrm{PM}_{1.0}$ concentrations. During these three tests, the air temperature in the room ranged from $24.6^{\circ} \mathrm{C}$ to $26.0^{\circ} \mathrm{C}$, whilst the relative humidity was between $42 \%$ and $53 \%$.

A previous study focused on the cooking of beef-steak [61]; in this study, a first steak (Steak 1) was cooked using the smaller cooker $(1.65 \mathrm{~kW}$ ), a second steak (Steak 2) was cooked using the medium one $(2.3 \mathrm{~kW})$ and a third steak (Steak 3$)$ using the larger one $(3 \mathrm{~kW})$. Every measurement lasted $26 \mathrm{~min}$. The PM concentrations due to the cooking of beef-steaks are reported in Table 3. As a result, the higher was the thermal power, the higher was the PM generation, especially regarding the finest particles $\left(\mathrm{PM}_{1.0}\right.$ and $\left.\mathrm{PM}_{2.5}\right)$. Some considerations are needed for the peak concentrations

Table 2: PM measurement during the cooking of polenta.

\begin{tabular}{lcccccc}
\hline & $\begin{array}{c}\text { Average } \\
\mathrm{PM}_{1.0}\end{array}$ & $\begin{array}{c}\text { Average } \\
\mathrm{PM}_{2.5}\end{array}$ & $\begin{array}{c}\text { Average } \\
\mathrm{PM}_{10}\end{array}$ & $\begin{array}{c}\text { Maximum } \\
\mathrm{PM}_{1.0}\end{array}$ & $\begin{array}{c}\text { Maximum } \\
\mathrm{PM}_{2.5}\end{array}$ & $\begin{array}{c}\text { Maximum } \\
\mathrm{PM}_{10}\end{array}$ \\
\hline Unit & $\mu \mathrm{g} \mathrm{m}^{3}$ & $\mu \mathrm{g} \mathrm{m}^{3}$ & $\mu \mathrm{g} \mathrm{m}^{3}$ & $\mu \mathrm{g} \mathrm{m}^{3}$ & $\mu \mathrm{g} \mathrm{m}^{3}$ & $\mu \mathrm{g} \mathrm{m}^{3}$ \\
Polenta 1 & 161.9 & 176.3 & 180.2 & 328.3 & 358.9 & 363.2 \\
Polenta 2 & 221.3 & 244.1 & 248.8 & 544.4 & 590.1 & 597.6 \\
Polenta 3 & 83.1 & 87.5 & 90.4 & 145,9 & 153 & 156.8 \\
\hline
\end{tabular}

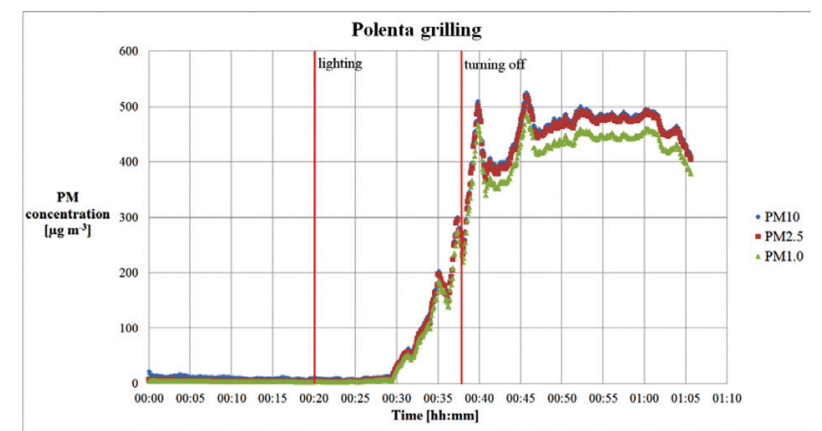

Figure 4: PM concentration during the cooking of Polenta 1; the vertical red lines indicate the lighting and the turning off the cooker. 
of $\mathrm{PM}_{10}$. It is clear that those values are significant, since they can reach even $6000 \mu \mathrm{g} \mathrm{m} \mathrm{m}^{3}$ for a few minutes. Particles may be generated also by the gas burning itself: natural gas was demonstrated to be the less important PM contributor among the traditional fuel used for cooking, even if an average $\mathrm{PM}_{10}$ concentration of $247 \mu \mathrm{g} \mathrm{m} \mathrm{m}^{3}$ was measured in a dwelling due to the only gas burning [65]. During the tests performed, the temperature of the pan was not measured. This could represent a useful additional variable to be monitored, in view of future measurement activities and for a better understanding of the process. In addition, monitoring the exchange rate of air in the rooms can provide information on the dilution effect on PM concentrations and should be taken into account for further developments of this research.

In general, for cooking activities, making use of an extractor hood placed above the cookers is advisable. Furthermore, the slow decrease in the values of PM suggests that the potential risk for health is not limited at the end time of the action itself but is prolonged in the case of permanence in the local.

The use of sprays showed very impactful effects on the IAQ, since a number of particles are released in air, with peaks of $\mathrm{PM}_{10}$ exceeding $2500 \mu \mathrm{g} \mathrm{m}^{3}$ (Table 4). The environmental conditions were represented by relative humidity between $38 \%$ and $50 \%$ and by room temperature between $23.2^{\circ} \mathrm{C}$ and $26.8^{\circ} \mathrm{C}$. Two consecutive peaks are visible, representing the two sprays in rapid succession (Fig. 5). The growth in PM concentrations is very fast and the maximum occurs in the instants following the use of the spray. However, whilst the performance of the particles of larger particle size $\left(\mathrm{PM}_{10}\right)$ is distinctly decreasing in time for the accelerated storage to the ground, the levels of $\mathrm{PM}_{2.5}$ and $\mathrm{PM}_{1.0}$ remain almost constant throughout the time of the measurement, with the exception of the final stage in which the exchange of air is facilitated by the opening of the window. In the third test, the recorded values are significantly lower because the two sprays had a slightly shorter duration

Table 3: PM measurements during steak cooking with different thermal power [61].

\begin{tabular}{lccrrrrr}
\hline & $\begin{array}{c}\text { Thermal } \\
\text { Power }\end{array}$ & $\begin{array}{c}\text { Average } \\
\mathrm{PM}_{1.0}\end{array}$ & $\begin{array}{c}\text { Average } \\
\mathrm{PM}_{2.5}\end{array}$ & $\begin{array}{c}\text { Average } \\
\mathrm{PM}_{10}\end{array}$ & $\begin{array}{c}\text { Maximum } \\
\mathrm{PM}_{1.0}\end{array}$ & $\begin{array}{c}\text { Maximum } \\
\mathrm{PM}_{2.5}\end{array}$ & $\begin{array}{c}\text { Maximum } \\
\mathrm{PM}_{10}\end{array}$ \\
\hline Unit & $\mathrm{kW}$ & $\mu \mathrm{g} \mathrm{\textrm {m } ^ { 3 }}$ & $\mu \mathrm{g} \mathrm{\textrm {m } ^ { 3 }}$ & $\mu \mathrm{g} \mathrm{m}^{3}$ & $\mu \mathrm{g} \mathrm{m}$ & $\mu \mathrm{g} \mathrm{m}^{3}$ & $\mu \mathrm{g} \mathrm{m}^{3}$ \\
Steak 1 & 1.65 & 371 & 521 & 1118 & 702 & 925 & 1720 \\
Steak 2 & 2.3 & 543 & 725 & 1348 & 1423 & 1690 & 2367 \\
Steak 3 & 3 & 1826 & 2383 & 3413 & 3245 & 4256 & 5567 \\
\hline
\end{tabular}

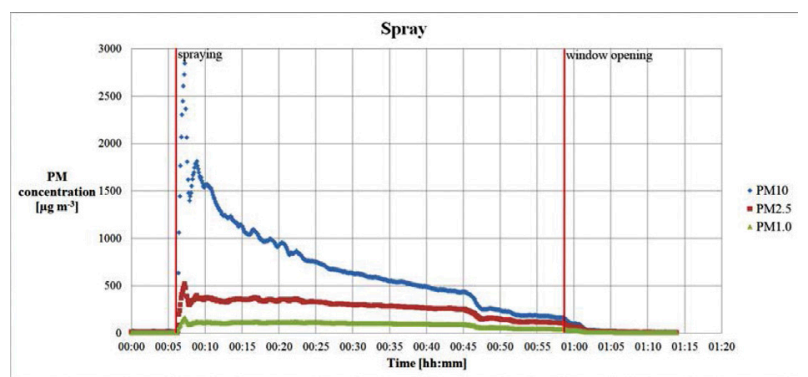

Figure 5: PM concentration during the use of Spray 2; the vertical red lines indicate the time of spraying and the window opening. 
Table 4: PM measurement during the use of spray.

\begin{tabular}{lcccccc}
\hline & $\begin{array}{c}\text { Average } \\
\mathrm{PM}_{1.0}\end{array}$ & $\begin{array}{c}\text { Average } \\
\mathrm{PM}_{2.5}\end{array}$ & $\begin{array}{c}\text { Average } \\
\mathrm{PM}_{10}\end{array}$ & $\begin{array}{c}\text { Maximum } \\
\mathrm{PM}_{1.0}\end{array}$ & $\begin{array}{c}\text { Maximum } \\
\mathrm{PM}_{2.5}\end{array}$ & $\begin{array}{c}\text { Maximum } \\
\mathrm{PM}_{10}\end{array}$ \\
\hline Unit & $\mu \mathrm{g} \mathrm{m}^{3}$ & $\mu \mathrm{g} \mathrm{m}^{3}$ & $\mu \mathrm{g} \mathrm{m}^{3}$ & $\mu \mathrm{g} \mathrm{m}^{3}$ & $\mu \mathrm{g} \mathrm{m}^{3}$ & $\mu \mathrm{g} \mathrm{m}^{3}$ \\
Spray 1 & 86.4 & 267.7 & 822.7 & 86.4 & 267.2 & 2143.0 \\
Spray 2 & 94.2 & 272.3 & 711.1 & 162.7 & 518.6 & 2846.2 \\
Spray 3 & 36.6 & 92.1 & 239.7 & 61.9 & 176.1 & 690.6 \\
\hline
\end{tabular}

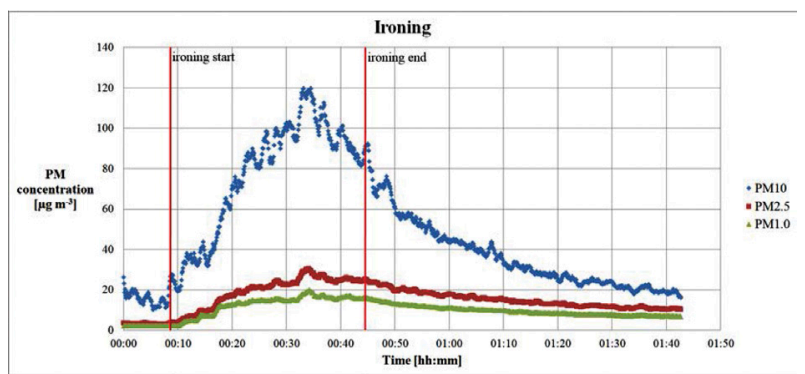

Figure 6: PM concentration during ironing (Iron 3); the vertical red lines indicate the start and end of ironing.

compared with the first two cases (about $1 \mathrm{~s}$ in total than the previous $2 \mathrm{~s}$ ). In a similar study, a peak of about $1000 \mu \mathrm{g} \mathrm{m}{ }^{3}$ was measured for $\mathrm{PM}_{2.5}$ [66].

The surveys showed a gradual and constant growth in the levels of PM while ironing, with peaks of $\mathrm{PM}_{10}$ slightly below $100 \mu \mathrm{g} \mathrm{m}^{3}$ (Table 5), given also by the re-suspension of dust due to the movement of the heads clothing in the room.

The values of $\mathrm{PM}_{2.5}$ always remained below the thresholds proposed by the guidelines; however, an hour after turning off the iron, the concentrations were triple compared with the underlying data recorded in the local before the activity (Fig. 6). During the tests, the room temperature ranged from $24.2^{\circ} \mathrm{C}$ to $28.1^{\circ} \mathrm{C}$, whilst the relative humidity was comprised between $39 \%$ and $52 \%$.

During the passage of the vacuum cleaner on the floor, the test gave satisfactory results because the concentrations of $\mathrm{PM}_{2.5}$ and $\mathrm{PM}_{1.0}$ underwent limited increases (Fig. 7). The room temperature during the test was comprised between $24.3^{\circ} \mathrm{C}$ and $24.9^{\circ} \mathrm{C}$, whilst the relative humidity was between $42 \%$ and $46 \%$. In contrast, the levels of $\mathrm{PM}_{10}$ suffered from a considerable increase for the raising of dust caused from the cleaner. $\mathrm{A} \mathrm{PM}_{10}$ peak of about $40 \mu \mathrm{g} \mathrm{m}{ }^{3}$ was reached during the test (Table 6). Considerably higher peaks were achieved in a previous study, with maximal $\mathrm{PM}_{2.5}$ concentrations between 2032 and $7182 \mu \mathrm{g} \mathrm{m}^{3}$ [64]. Slightly higher values with respect to the present study were measured in an experimental chamber during vacuuming [67]. A gradual increase in $\mathrm{PM}_{2.5}$ and $\mathrm{PM}_{1.0}$ concentrations is visible $25 \mathrm{~min}$ after concluding the vacuuming. Further investigations, by prolonging the duration of the measurement, are needed to evaluate the temporal extent of the resuspension of the finest fractions. Exposure to particulate matter should not be overlooked if the cleaning go on for a long time or occur in particularly dusty environments, where there is a greater particle suspension. 
Table 5: PM measurement during ironing.

\begin{tabular}{lcccccc}
\hline & $\begin{array}{c}\text { Average } \\
\mathrm{PM}_{1.0}\end{array}$ & $\begin{array}{c}\text { Average } \\
\mathrm{PM}_{2.5}\end{array}$ & $\begin{array}{c}\text { Average } \\
\mathrm{PM}_{10}\end{array}$ & $\begin{array}{c}\text { Maximum } \\
\mathrm{PM}_{1.0}\end{array}$ & $\begin{array}{c}\text { Maximum } \\
\mathrm{PM}_{2.5}\end{array}$ & $\begin{array}{c}\text { Maximum } \\
\mathrm{PM}_{10}\end{array}$ \\
\hline Unit & $\mu \mathrm{g} \mathrm{m}^{3}$ & $\mu \mathrm{g} \mathrm{m}^{3}$ & $\mu \mathrm{g} \mathrm{m}^{3}$ & $\mu \mathrm{g} \mathrm{m}^{3}$ & $\mu \mathrm{g} \mathrm{m}^{3}$ & $\mu \mathrm{g} \mathrm{m}^{3}$ \\
Iron 1 & 13.5 & 18.2 & 56.7 & 20.8 & 27.3 & 86.9 \\
Iron 2 & 23.3 & 28.3 & 50.8 & 30.0 & 37.4 & 101.9 \\
Iron3 & 12.4 & 18.8 & 67.0 & 20.0 & 30.4 & 119.8 \\
\hline
\end{tabular}

Table 6: PM measurement during vacuum cleaning.

\begin{tabular}{lcccccc}
\hline & $\begin{array}{c}\text { Average } \\
\mathrm{PM}_{1.0}\end{array}$ & $\begin{array}{c}\text { Average } \\
\mathrm{PM}_{2.5}\end{array}$ & $\begin{array}{c}\text { Average } \\
\mathrm{PM}_{10}\end{array}$ & $\begin{array}{c}\text { Maximum } \\
\mathrm{PM}_{1.0}\end{array}$ & $\begin{array}{c}\text { Maximum } \\
\mathrm{PM}_{2.5}\end{array}$ & $\begin{array}{c}\text { Maximum } \\
\mathrm{PM}_{10}\end{array}$ \\
\hline Unit & $\mu \mathrm{g} \mathrm{m}^{3}$ & $\mu \mathrm{g} \mathrm{m}^{3}$ & $\mu \mathrm{g} \mathrm{m}^{3}$ & $\mu \mathrm{g} \mathrm{m}^{3}$ & $\mu \mathrm{g} \mathrm{m}^{3}$ & $\mu \mathrm{g} \mathrm{m}^{3}$ \\
Vacuum cleaner & 6.7 & 8.2 & 21.7 & 12.8 & 15.2 & 39.1 \\
\hline
\end{tabular}

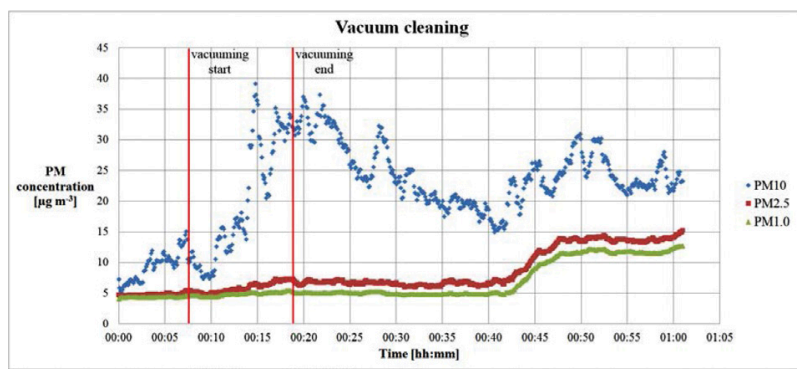

Figure 7: PM concentration during vacuum cleaning; the vertical red lines indicate the start and end of vacuuming.

With the exception of the test on the use of sprays, no conversion of smaller particles to larger ones was observed, contrarily to what would be expected due to condensation phenomena. The duration of the measurements may have had a certain influence, considering that the process can require up to some hours to occur and be visible [48].

From the point of view of the analytical technology adopted, the GRIMM analyser 1.108 offers the interesting opportunity of performing accurate measurements with a portable solution. However, particles with aerodynamic diameter lower than $300 \mathrm{~nm}$ (and, thus, also UFP) cannot be detected by this instrument. This is a limitation that does not allow accounting for the importance of nanoparticles and their potential impacts on human health, even though the GRIMM analyser has been applied in important studies in the literature [21,39,64,65].

\section{CONCLUSIONS}

In the last decades, resolute steps towards the limitation of emissions into the atmosphere and the control of PM concentrations in cities have been made. On the contrary, the prevailing idea that 
indoor environments do not represent a particular issue compared with the outside world, resulted in a delay of research in this field.

Only in recent years, the problem of dust in indoor environment has raised concern by the scientific world, trying trigger a debate on limit values for PM not to be exceeded in indoor environments, with the purpose of protecting human health, both in terms of acute and chronic effects.

Following a series of tests, operated with the aim of controlling the amount of dust released into the environment through the three size classes of $\mathrm{PM}_{10}, \mathrm{PM}_{2.5}, \mathrm{PM}_{1.0}$, it emerged that the common activities that take place daily in domestic environments play a primary role in indoor air pollution.

The study found that cooking activities and the use of deodorant sprays are the sources that produce the higher indoor PM concentrations and are without doubt the most impactful for the health of the home sites.

During the presented tests, the time evolution of the PM was observed. A rapid growth towards the peak concentration was followed by a slow decrease in the levels recorded, indicating that the environments should be considered unhealthy even in the moments subsequent to the conclusion of the source of particulate, if not properly aerated.

Moreover, the thermal power of cookers can influence PM emission during beef-steak cooking. Using the most powerful cooker, the $\mathrm{PM}_{10}$ production resulted three times higher than using the smaller one. In particular, this increase is connected with a significant generation of the smaller size fraction $\left(\mathrm{PM}_{1.0}\right)$, with obvious repercussions on the human health. However, further investigation is needed especially in terms of quantification of the role of UFP, which cannot be detected by the analyser adopted here.

\section{REFERENCES}

[1] Diapouli, E., Chaloulakou, A. \& Koutrakis, P., Estimating the concentration of indoor particles of outdoor origin: a review. Journal of the Air and Waste Management Association, 63(10), pp. 1113-1129, 2013. doi: http://dx.doi.org/10.1080/10962247.2013.791649

[2] Buonanno, G., Fuoco, F.C., Morawska, L. \& Stabile, L., Airborne particle concentrations at schools measured at different spatial scales. Atmospheric Environment, 67, pp. 38-45, 2013. doi: http://dx.doi.org/10.1016/j.atmosenv.2012.10.048

[3] Commodore, A.A., Hartinger, S.M., Lanata, C.F., Mäusezahl, D., Gil, A.I., Hall, D.B., AguilarVillalobos, M. \& Naeher, L.P., A pilot study characterizing real time exposures to particulate matter and carbon monoxide from cookstove related wood smoke in rural Peru. Atmospheric Environment,79, pp. 380-388, 2013. doi: http://dx.doi.org/10.1016/j.atmosenv.2013.06.047

[4] Ionescu, G., Apostol, T., Rada, E.C., Ragazzi, M. \& Torretta, V., Critical analysis of strategies for PM reduction in urban areas. Scientific Bulletin, Series D, 75(2), pp. 175-186, 2013.

[5] Pey, J., Van Drooge, B.L., Ripoll, A., Moreno, T., Grimalt, J.O., Querol, X. \& Alastuey, A., An evaluation of mass, number concentration, chemical composition and types of particles in a cafeteria before and after the passage of an antismoking law. Particuology, 11(5), pp. 527-532, 2013. doi: http://dx.doi.org/10.1016/j.partic.2013.02.007

[6] Ciuta, S., Schiavon, M., Chistè, A., Ragazzi, M., Rada, E.C., Tubino, M., Badea, A. \& Apostol, T., Role of feedstock transport in the balance of primary PM emissions in two case-studies: RMSW incineration vs. sintering. Scientific Bulletin, Series D, 74(1), pp. 211-218, 2012.

[7] Torretta, V., Rada, E.C., Panaitescu, V. \& Apostol, T., Some considerations on particulate generated by traffic. Scientific Bulletin, Series D, 74(4), pp. 241-248, 2012.

[8] Ragazzi, M. \& Rada, E.C., Multi-step approach for comparing the local air pollution contributions of conventional and innovative MSW thermo-chemical treatments. Chemosphere, 89(6), pp. 694-701, 2012. http://dx.doi.org/10.1016/j.chemosphere.2012.06.024 
[9] Vecchi, R., Marcazzan, G., Valli, G., Ceriani, M. \& Antoniazzi, C., The role of atmospheric dispersion in the seasonal variation of $\mathrm{PM}_{1}$ and $\mathrm{PM}_{25}$ concentration and composition in the urban area of Milan (Italy). Atmospheric Environment, 38(27), pp. 4437-4446, 2004. doi: http:// dx.doi.org/10.1016/j.atmosenv.2004.05.029

[10] Mues, A., Manders, A., Schaap, M., van Ulft, L.H., van Meijgaard, E. \& Builtjes, P., Differences in particulate matter concentrations between urban and rural regions under current and changing climate conditions. Atmospheric Environment, 80, pp. 232-247, 2013. doi: http:// dx.doi.org/10.1016/j.atmosenv.2013.07.049

[11] Makri, A. \& Stilianakis, N., Vulnerability to air pollution health effects. International Journal of Hygiene and Environmental Health, 211(3-4), pp. 326-336, 2008. doi: http://dx.doi. org/10.1016/j.ijheh.2007.06.005

[12] Kaur, S., Senthilkumar, K., Verma, V.K., Kumar, B., Kumar, S., Katnoria, J.K. \& Sharma, C.S., Preliminary analysis of polycyclic aromatic hydrocarbons in air particles $\left(\mathrm{PM}_{10}\right)$ in Amritsar, India: sources, apportionment, and possible risk implications to humans. Archives of Environmental Contamination and Toxicology, 65(3), pp. 382-395, 2013. doi: http://dx.doi. org/10.1007/s00244-013-9912-6

[13] Ragazzi, M., Tirler, W., Angelucci, G., Zardi, D. \& Rada, E.C., Management of atmospheric pollutants from waste incineration processes: the case of Bozen. Waste Management and Research, 31(3), pp. 235-240, 2013. doi: http://dx.doi.org/10.1177/0734242x12472707

[14] Hallquist, Å.M., Jerksjö, M., Fallgren, H., Westerlund, J. \& Sjödin Å., Particle and gaseous emissions from individual diesel and CNG buses. Atmospheric Chemistry and Physics, 13(10), pp. 5337-5350, 2013. doi: http://dx.doi.org/10.5194/acp-13-5337-2013

[15] Wu, C.L., Chao, C.Y.H., Sze-To, G.N., Wan, M.P. \& Chan T.C., Ultrafine particle emissions from cigarette smouldering, incense burning, vacuum cleaner motor operation and cooking. Indoor and Built Environment, 21(6), pp. 782-796, 2012. doi: http://dx.doi. org/10.1177/1420326x11421356

[16] Li, M., Mcdow, S.R., Tollerud, D.J. \& Mazurek, M.A., Seasonal abundance of organic molecular markers in urban particulate matter from Philadelphia, PA. Atmospheric Environment, 40, pp. 2260-2273, 2006. doi: http://dx.doi.org/10.1016/j.atmosenv.2005.10.025

[17] Keary, J., Jennings, S.G., O’Connor, T.C., Mcmanus, B. \& Lee, M., PM 10 concentration measurements in Dublin city. Environmental Monitoring and Assessment, 52, pp. 3-18, 1998. doi: http://dx.doi.org/10.1007/978-94-011-5127-6_1

[18] Toledo, V.E., De Almeida Júnior, P.B., Quiterio, S.L., Arbilla, G., Moreira, A., Escaleira V. \& Moreira, J.C., Evaluation of levels, sources and distribution of toxic elements in $\mathrm{PM}_{10}$ in a suburban industrial region, Rio de Janeiro, Brazil. Environmental Monitoring and Assessment, 139, pp. 49-59, 2008. doi: http://dx.doi.org/10.1007/s10661-007-9815-y

[19] Daher, N., Saliba, N.A., Shihadeh, A.L., Jaafar, M., Baalbaki, R. \& Sioutas, C., Chemical composition of size-resolved particulate matter at near-freeway and urban background sites in the greater Beirut area. Atmospheric Environment, 80, pp. 96-106, 2013. doi: http://dx.doi. org/10.1016/j.atmosenv.2013.08.004

[20] Malandrino, M., Di Martino, M., Ghiotti, G., Geobaldo, F., Grosa, M.M., Giacomino, A. \& Abollino, O., Inter-annual and seasonal variability in $\mathrm{PM}_{10}$ samples monitored in the city of Turin (Italy) from 2002 to 2005. Microchemical Journal, 107, pp. 76-85, 2013. doi: http:// dx.doi.org/10.1016/j.microc.2012.05.026

[21] Nasir, Z.A. \& Colbeck, I., Particulate pollution in different housing types in a UK suburban location. Science of the Total Environment, 445-446, pp. 165-176, 2013. doi: http://dx.doi. org/10.1016/j.scitotenv.2012.12.042 
[22] Efe, S.I. \& Efe, A.T., Spatial distribution of particulate matter $\left(\mathrm{PM}_{10}\right)$ in Warri metropolis, Nigeria. Environmentalist, 28, pp. 385-394, 2008. doi: http://dx.doi.org/10.1007/s10669-007-9154-0

[23] Vujic, B., Pavlovic, A., Vujic, G. \& Jevtic, D., Assessment of concentration levels of particulate matters (PM10, TSP and BS) in the area of Zrenjanin, Vojvodina, Serbia. Chemistry Magazine, 61, pp. 91-1007, 2010.

[24] Perrone, M.G., Larsen, B.R., Ferrero, L., Sangiorgi, G., De Gennaro, G., Udisti, R., Zangrando, R., Gambaro, A. \& Bolzacchini, E., Sources of high $\mathrm{PM}_{2.5}$ concentrations in Milan, Northern Italy: molecular marker data and CMB modelling. Science of the Total Environment, 414, pp. 343-355, 2012. doi: http://dx.doi.org/10.1016/j.scitotenv.2011.11.026

[25] Toscano, G., Gambaro, A., Moret, I., Capodaglio, G., Turetta, C. \& Cescon P., Trace metals in aerosol at Terra Nova Bay, Antarctica. Journal of Environmental Monitoring, 7, pp. 1275-1280, 2005. doi: http://dx.doi.org/10.1039/b507337p

[26] Rada, E.C., Ragazzi, M. \& Malloci, E., Levoglucosan as a tracer of wood combustion in an alpine region. Environmental Technology, 33(9), pp. 989-994, 2012. doi: http://dx.doi.org/10. 1080/09593330.2011.604858

[27] Kousa, A., Oglesby, L., Koistinen, K., Künzli, N. \& Jantunen M., Exposure chain of urban air $\mathrm{PM}_{2.5}$ - associations between ambient fixed site, residential outdoor, indoor, workplace and personal exposures in four European cities in the EXPOLIS-study. Atmospheric Environment, 36, pp. 3031-3039, 2002. doi: http://dx.doi.org/10.1016/s1352-2310(02)00232-7

[28] Contini, D., Gambaro, A., Belosi, F., De Pieri, S., Cairns, W., Donateo, A., Zanotto, E. \& Citron, M., The direct influence of ship traffic on atmospheric $\mathrm{PM}_{2.5}, \mathrm{PM}_{10}$ and PAHs in Venice. Journal of Environmental Management, 92, pp. 2119-2129, 2011. doi: http://dx.doi. org/10.1016/j.jenvman.2011.01.016

[29] Kwak, J.H., Kim, H., Lee, J. \& Lee, S., Characterization of non-exhaust coarse and fine particles from on-road driving and laboratory measurements. Science of the Total Environment, 458-460, pp. 273-282, 2013. doi: http://dx.doi.org/10.1016/j.scitotenv.2013.04.040

[30] Rada, E.C., Ragazzi, M., Brini, M., Marmo, L., Zambelli, P., Chelodi, M. \& Ciolli, M., Perspectives of low-cost sensors adoption for air quality monitoring. UPB Scientific Bulletin, Series D, 74(2), pp. 243-250, 2012.

[31] Rada, E.C., Ragazzi, M., Antolini, D., Malloci, E. \& Venturi, M., In-door air-measurements of $\mathrm{PM}_{10}$ in different conditions. Proceedings of International Symposium on Environmental Science and Technology, Science Press USA, Inc.: Beijing, pp. 571-577, 2009.

[32] Buonanno, G., Morawska, L., Stabile, L. \& Viola, A., Exposure to particle number, surface area and PM concentrations in pizzerias. Atmospheric Environment, 44, pp. 3963-3969, 2010. doi: http://dx.doi.org/10.1016/j.atmosenv.2010.07.002

[33] Wang, X., Bi, X., Sheng, G. \& Fu, J., Hospital indoor $\mathrm{PM}_{10} / \mathrm{PM}_{2.5}$ and associated trace elements in Guangzhou, China. Science of the Total Environment, 366, pp. 124-135, 2006. doi: http://dx.doi.org/10.1016/j.scitotenv.2005.09.004

[34] Habil, M., Massey, D.D. \& Taneja, A., Exposure of children studying in schools of India to PM levels and metal contamination: sources and their identification. Air Quality, Atmosphere and Health, 6(3), pp. 575-587, 2013. doi: http://dx.doi.org/10.1007/s11869-013-0201-3

[35] Chuang, H.C., Jones, T. \& BéruBé, K., Combustion particles emitted during church services: implications for human respiratory health. Environment International, 40, pp. 137-142, 2012. doi: http://dx.doi.org/10.1016/j.envint.2011.07.009

[36] Kim, Y.S., Kim, J.T., Kim, I.W., Kim, J.C. \& Yoo, C., Multivariate monitoring and local interpretation of indoor air quality in Seoul's metro system. Environmental Engineering Science, 27, pp. 721-731, 2010. doi: http://dx.doi.org/10.1089/ees.2009.0261 
[37] Grabow, K., Still, D. \& Bentson, S., Test kitchen studies of indoor air pollution from biomass cookstoves. Energy for Sustainable Development, 17(5), pp. 458-462, 2013. doi: http://dx.doi. org/10.1016/j.esd.2013.05.003

[38] He, C., Morawska, L., Hitchins, J. \& Gilbert, D., Contribution from indoor sources to particle number and mass concentrations in residential house. Atmospheric Environment, 38, pp. 3405-3415, 2004. doi: http://dx.doi.org/10.1016/j.atmosenv.2004.03.027

[39] Hassanvand, M.S., Naddafi, K., Faridi, S., Arhami, M., Nabizadeh, R., Sowlat, M.H., Pourpak, Z., Rastkari, N., Momeniha, F., Kashani, H., Gholampour, A., Nazmara, S., Alimohammadi, M., Goudarzi, G. \& Yunesian, M., Indoor/outdoor relationships of PM10, PM2.5, and PM1 mass concentrations and their water-soluble ions in a retirement home and a school dormitory. Atmospheric Environment, 82, pp. 375-382, 2014. doi: http://dx.doi.org/10.1016/j.atmosenv.2013.10.048

[40] Ohura, T., Amagai, T., Sugiyama, T., Fusaya, M. \& Matsushita, H., Characteristics of particle matter and associated polycyclic aromatic hydrocarbons in indoor and outdoor air in two cities in Shizuoka, Japan. Atmospheric Environment, 38(14), pp. 2045-2054, 2004. doi: http:// dx.doi.org/10.1016/j.atmosenv.2004.01.038

[41] Geller, M.D., Chang, M., Sioutas, C., Ostro, B.D. \& Lipsett, M.J., Indoor/outdoor relationship and chemical composition of fine and coarse particles in the southern California deserts. Atmospheric Environment, 36(6), pp. 1099-1110, 2002. doi: http://dx.doi.org/10.1016/s13522310(01)00340-5

[42] Naumova, Y.Y., Offenberg, J.H., Eisenreich, S.J., Meng, Q., Polidori, A., Turpin, B.J., Weisel, C.P., Morandi, M.T., Colome, S.D., Stock, T.H., Winer, A.M., Alimokhtari, S., Kwon, J., Maberti, S., Shendell, D., Jones, J. \& Farrar, C., Gas/particle distribution of polycyclic aromatic hydrocarbons in coupled outdoor/indoor atmospheres. Atmospheric Environment, 37(5), pp. 703-719, 2003. doi: http://dx.doi.org/10.1016/s1352-2310(02)00820-8

[43] Sangiorgi, G., Ferrero, L., Ferrini, B.S., Lo Porto, C., Perrone, M.G., Zangrando, R., Gambaro, A., Lazzati, Z. \& Bolzacchini, E., Indoor airborne particle sources and semi-volatile partitioning effect of outdoor fine PM in offices. Atmospheric Environment, 65, pp. 205-214, 2013. doi: http://dx.doi.org/10.1016/j.atmosenv.2012.10.050

[44] Pegas, P.N., Nunes, T., Alves, C.A., Silva, J.R., Vieira, S.L.A., Caseiro, A. \& Pio, C.A., Indoor and outdoor characterisation of organic and inorganic compounds in city centre and suburban elementary schools of Aveiro, Portugal. Atmospheric Environment, 55, pp. 80-89, 2012. doi: http://dx.doi.org/10.1016/j.atmosenv.2012.03.059

[45] Abdullahi, K.L., Delgado-Saborit, J.M. \& Harrison, R.M., Emissions and indoor concentrations of particulate matter and its specific chemical components from cooking: a review. Atmospheric Environment, 71, pp. 260-294, 2013. doi: http://dx.doi.org/10.1016/j.atmosenv.2013.01.061

[46] Hussein, T., Hämeri, K., Heikkinen, M.S.A. \& Kulmala, M., Indoor and outdoor particle size characterization at a familyhouse in Espoo-Finland. Atmospheric Environment, 39, pp. 36973709, 2005. doi: http://dx.doi.org/10.1016/j.atmosenv.2005.03.011

[47] Kelly, F.J. \& Fussel, J.C., Size, source and chemical composition as determinants of toxicity attributable to ambient particulate matter. Atmospheric Environment, 60, pp. 504-526, 2012. doi: http://dx.doi.org/10.1016/j.atmosenv.2012.06.039

[48] Hovorka, J. \& Braniš, M., New particle formation and condensational growth in a large indoor space. Atmospheric Environment, 45(16), pp. 2736-2749, 2011. doi: http://dx.doi. org/10.1016/j.atmosenv.2011.02.039

[49] WHO, 2003. Health aspects of air pollution with particulate matter, ozone and nitrogen dioxide. Report on a WHO Working Group. 
[50] Knibbs, L.D., Cole-Hunter, T. \& Morawska, L., A review of commuter exposure to ultrafine particles and its health effects. Atmospheric Environment, 45(16), pp. 2611-2622, 2011. doi: http://dx.doi.org/10.1016/j.atmosenv.2011.02.065

[51] Franck, U, Herbarth, O., Röder, S., Schlink, U., Borte, M., Diez, U., Krämer, U. \& Lehmann, I., Respiratory effects of indoor particles in young children are size dependent. Science of the Total Environment, 409(9), pp. 1621-1631, 2011. doi: http://dx.doi.org/10.1016/j.scitotenv.2011.01.001

[52] Odabasi, M., Ongan, O. \& Cetin, E., Quantitative analysis of volatile organic compounds (VOCs) in atmospheric particles. Atmospheric Environment, 39(20), pp. 3763-3770, 2005. doi: http://dx.doi.org/10.1016/j.atmosenv.2005.02.048

[53] Gupta, S., Kumar, K., Srivastava, A., Srivastava, A. \& Jain, V.K., Size distribution and source apportionment of polycyclic aromatic hydrocarbons (PAHs) in aerosol particle samples from the atmospheric environment of Delhi, India. Science of the Total Environment, 429(22), pp. 4674-4680, 2011. doi: http://dx.doi.org/10.1016/j.scitotenv.2011.08.008

[54] USEPA, Guidelines on exceptions to data requirements for determining attainment of particulate matter standards, EPA 450 4.87.005, 1987.

[55] USEPA, Guideline on data handling conventions for the PM NAAQS, EPA 454/R-99-008, 1999.

[56] Directive 1999/30/EC of 22 April 1999 relating to limit values for sulphur dioxide, nitrogen dioxide and oxides of nitrogen, particulate matter and lead in ambient air, 1999.

[57] Directive 2008/50/EC of the European Parliament and of the Council of 21 May 2008 on ambient air quality and cleaner air for Europe, 2008.

[58] ASHRAE, Ventilation for Acceptable Indoor Air Quality, ANSI/ASHRAE Standard 62.1, 2007.

[59] GRIMM Aerosol, available at www.grimm-aerosol.com/en/Indoor-Air-Quality/2/2/index.html.

[60] Massey, D., Kulshrestha, A., Masih, J. \& Taneja, A., Seasonal trends of $\mathrm{PM}_{10}, \mathrm{PM}_{5.0}, \mathrm{PM}_{2.5} \& \mathrm{PM}_{1.0}$ in indoor and outdoor environments of residential homes located in North-Central India. Building and Environment, 47, pp. 223-231, 2012. doi: http://dx.doi.org/10.1016/j.buildenv.2011.07.018

[61] Schiavon, M., Rada, E.C., Ragazzi, M. \& Antolini, D., Indoor measurements of particulate matter during beef-steak cooking under different conditions. WIT Transactions on Ecology and the Environment, 176, pp. 255-264, 2013. doi: http://dx.doi.org/10.2495/esus130221

[62] Beam, available at http://www.beamvac.com/usa/docs/2007_clinical_sheet.pdf.

[63] See, S.W. \& Balasubramanian, R., Chemical characteristics of fine particles emitted from different gas cooking methods. Atmospheric Environment, 42, pp. 8852-8862, 2008. doi: http:// dx.doi.org/10.1016/j.atmosenv.2008.09.011

[64] Holmes, H.A., Pardyjak, E.R., Speckart, S.O. \& Alexander, D., Comparison of indoor/outdoor carbon content and time resolved PM concentrations for gas and biomass cooking fuels in Nogales, Sonora, Mexico. Atmospheric Environment, 45, pp. 7600-7611, 2011. doi: http://dx.doi. org/10.1016/j.atmosenv.2010.12.057

[65] Kim, K.-H., Pandey, S.K., Kabir, E., Susaya, J. \& Brown, R.J.C., The modern paradox of unregulated cooking activities and indoor air quality. Journal of Hazardous Materials, 195, pp. 1-10, 2011. doi: http://dx.doi.org/10.1016/j.jhazmat.2011.08.037

[66] Glytsos, T., Ondracek, J., Dzumbova, L., Kopanakis, I. \& Lazaridis, M., Characterization of particulate matter concentrations during controlled indoor activities. Atmospheric Environment, 44, pp. 1539-1549, 2010. doi: http://dx.doi.org/10.1016/j.atmosenv.2010.01.009

[67] Montoya, L.D. \& Hildemann, L.M., Size distributions and height variations of airborne particulate matter and cat allergen indoors immediately following dust-disturbing activities. Journal of Aerosol Science, 36(5-6), pp. 735-749, 2005. doi: http://dx.doi.org/10.1016/j.jaerosci.2004.11.004 